\title{
PENGEMBANGAN PROTOTYPE SISTEM MONITORING KETINGGIAN AIR UNTUK PERINGATAN DINI
}

\author{
Ade Bastian"), Ardi Mardiana ${ }^{2)}$, Riki Riyanto ${ }^{3)}$ \\ Prodi Informatika, Fakultas Teknik, Universitas Majalengka \\ bastiandicaprio@gmail.com, aim@ft.unma.ac.id, Rikiriyanto22@gmail.com
}

\begin{abstract}
ABSTRACS
Indonesia is a country with high rainfall at the rainy season; it can last four months within a year. With the increasing of development in the urban areas, causing the shortage of water absorption area. Many people disposing trash in the water flow is also a factor in the occurrence of floods. Flooding may cause the loss of property; it can also cause loss of life. It takes the presence of monitoring and warning system in order to avoid the occurrence of casualties. And minimize material losses incurred as a result of flooding By using prototype method A water quality monitoring system was created with arduino uno R3 and HCSRO4 sensors. System Monitoring of water levels is made to be easily accessible anytime and anywhere. System warnings are also made to be able to deliver warnings quickly, and have territory wide coverage. By using this system can be monitored through the web service. So this system can help the user, avoid or can suppress the loss Arising from the flood that occurred.
\end{abstract}

Keywords - The flood monitoring system, Flood warning system, Arduino Uno R3

\section{PENDAhULUAN}

Bencana alam adalah salah satu fenomena yang dapat menimbulkan risiko atau bahaya terhadap kehidupan manusia, baik kerugian harta benda maupun korban jiwa manusia. Salah satu bencana alam yang sering terjadi di Indonesia yaitu banjir. Badan Penanggulangan Bencana Nasional mencatat, selama Januari-September 2016 telah terjadi 1.704 bencana, 584 kali di antaranya adalah banjir dan sebanyak 47 kali banjir disertai tanah longsor. Kewaspadaan terhadap ancaman bencana perlu ditingkatkan untuk mencegah terjadinya korban jiwa. Periode Januari-September 2016, bencana di Indonesia telah menelan 411 korban meninggal dunia, 128 jiwa di antaranya disebabkan oleh bencana banjir. (Nugroho 2016)

Hal ini menjadi sebuah perhatian bagi Badan Penanggulangan Bencana Daerah (BPBD) seluruh Indonesia.

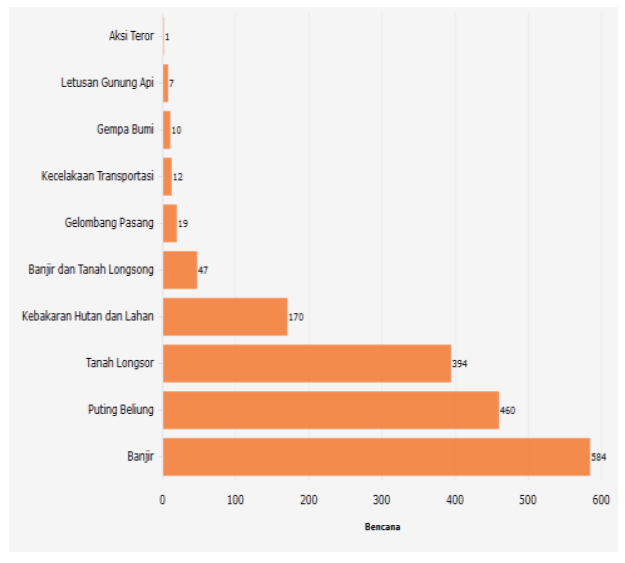

Gambar 1. Jumlah Kejadian Bencana di Indonesia

Banjir banyak menimbulkan kerugian bagi masyarakat yang terkena banjir. Dampak dari banjir ini memang sangat luar biasa, rumah rusak karena terendam banjir, barang-barang perabotan rumah tangga hanyut dan rusak. Ditambah bila penduduk yang memiliki usaha rumahan bisa terganggu aktifitas produksinya sehingga mengakibatkan kerugian, selain itu banjir juga banyak menimbulkan korban jiwa yang tidak sedikit.

\section{Kajian Literatur \\ a. Arduino Uno R3}

Arduino adalah papan rangkaian elektronik (electronic board) open source yang mempunyai masukan dan keluaran serta terdapat komponen utama untuk pengendali program yang bisa ditulis dan dihapus dengan cara khusus yaitu sebuah chip mikrokontroler berbasis ATMega328. Microcontroller itu sendiri adalah suatu chip atau IC (Integrated circuit) yang bisa diprogram menggunakan komputer. Program yang direkam bertujuan agar rangkaian elektronik dapat membaca input, memperoses dan kemudian menghasilkan output sesuai yang diinginkan. Hasilnya bisa berupa sinyal, tegangan, lampu, suara, getaran, gerakan dan sebagainya. (Muhammad haekal, dkk, 2012). Saat ini Arduino sangat populer, banyak pemula maupun profesional ikut mengembangkan aplikasi elektronik menggunakan arduino. Bahasa pemrograman yang digunakan untuk mengontrol

Computer Science | Industrial Engineering | Mechanic Engineering | Civil Engineering 
Arduino adalah bahasa pemrgoraman C. (Purnomo dan pramana, arduino 2015)

\section{b. Sensor Ultrasonik}

Sensor ini merupakan sensor ultrasonik siap pakai, satu alat yang berfungsi sebagai pengirim, penerima, dan pengontrol gelombang ultrasonik. Alat ini bisa digunakan untuk mengukur jarak benda dari $2 \mathrm{~cm}-4 \mathrm{~m}$ dengan akurasi $3 \mathrm{~mm}$. Alat ini memiliki 4 pin, pin Vcc, Gnd, Trigger, dan Echo. Pin Vec untuk listrik positif dan Gnd untuk ground-nya. Pin Trigger untuk trigger keluarnya sinyal dari sensor dan pin Echo untuk menangkap sinyal pantul dari benda. (Sakti, e, mei 2014)

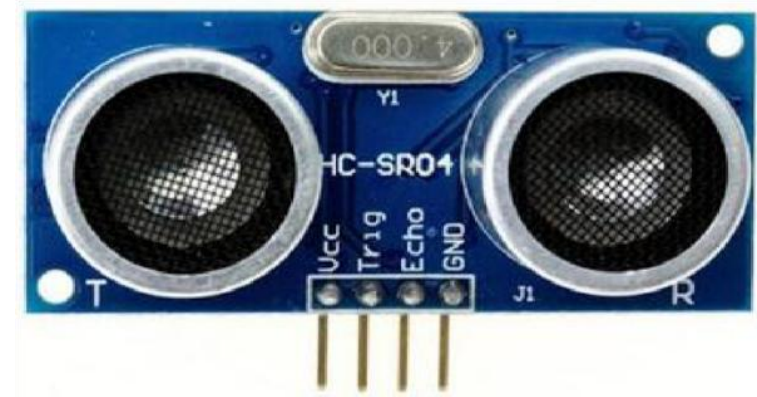

Gambar 2. Sensor Ultrasonik HC-SR04

Cara menggunakan alat ini yaitu: ketika kita memberikan tegangan positif pada pin Trigger selama 10uS, maka sensor akan mengirimkan 8 step sinyal ultrasonik dengan frekuensi $40 \mathrm{kHz}$. Selanjutnya, sinyal akan diterima pada pin Echo. Untuk mengukur jarak benda yang memantulkan sinyal tersebut, maka selisih waktu ketika mengirim dan menerima sinyal digunakan untuk menentukan jarak benda tersebut. Rumus untuk menghitungnya sudah saya sampaikan di atas.

Berikut adalah visualisasi dari sinyal yang dikirimkan oleh sensor HC-SR04 :

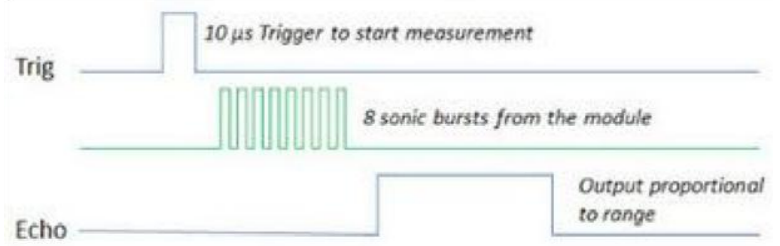

Gambar 2.15 Sistem pewaktu pada sensor HC- SR04

\section{METODE PENELITIAN \\ a. Kerangka Penelitian}

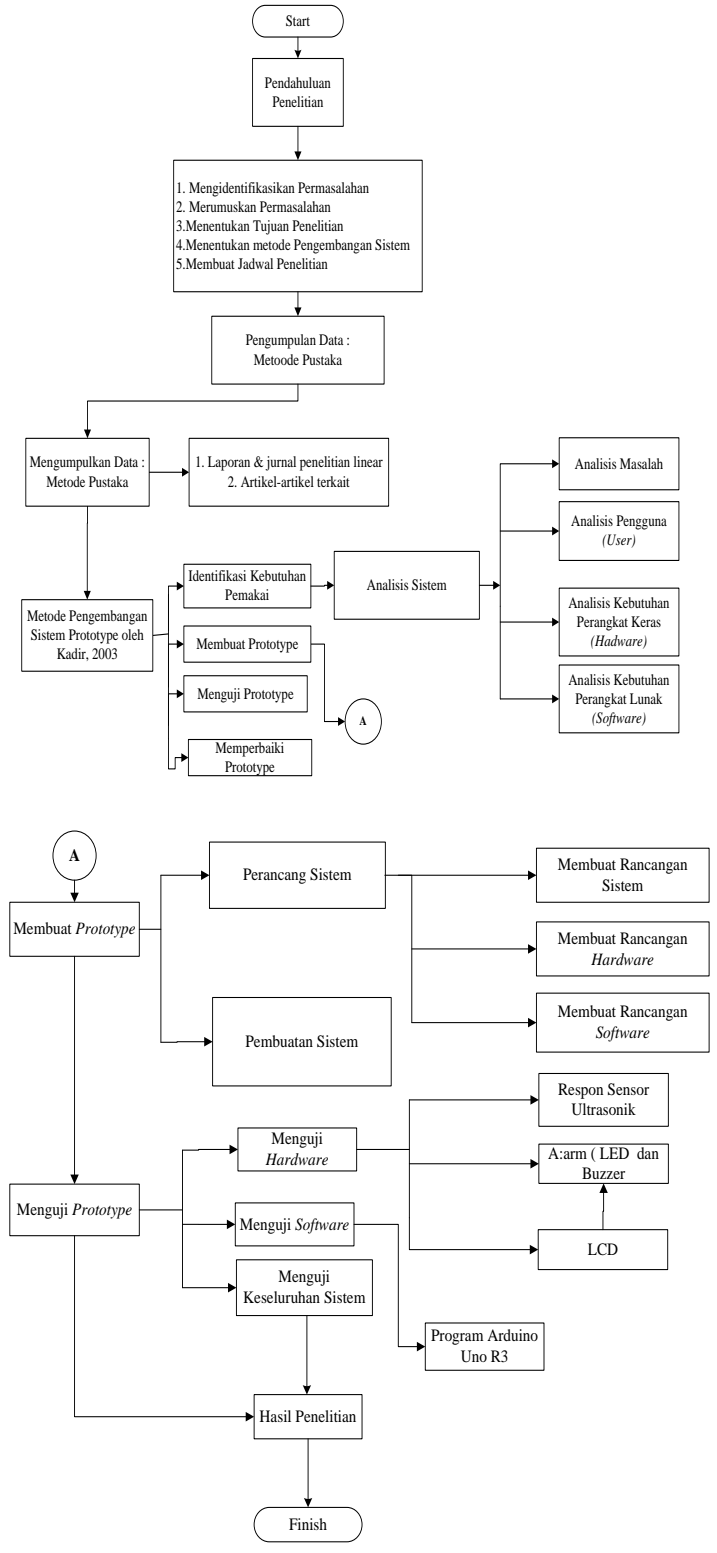

Gambar 3. Kerangka Penelitian

\section{b. Metode Pengembangan Sistem}

(Kadir, a.2003) Metode pengembangan sistem yang digunakan untuk membuat peringatan dini banjir menggunakan sensor ultrasonik HC-SR04 adalah model prototype. Proses-proses yang terdapat dalam model protoype diantaranya adalah : 


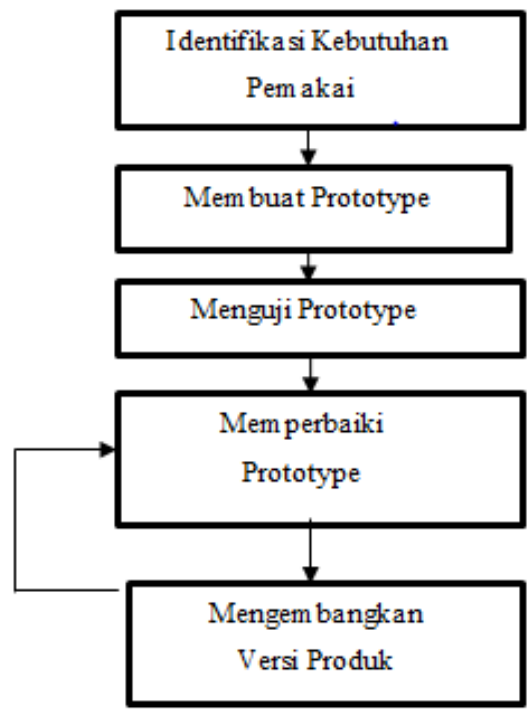

Gambar 4. Model Prototype

Identifikasi Kebutuhan Sistem Metode pengembangan sistem yang digunakan untuk membuat peringatan dini banjir menggunakan sensor ultrasonik HC-SR04 adalah model prototype. Proses-proses yang terdapat dalam model protoype diantaranya adalah :

\section{Identifikasi Kebutuhan Sistem}

Untuk membangun Sistem yang di buat yaitu dengan membuat sebuah sistem perangkat keras (hardware) yang mampu mendeteksi ketinggian air secara otomatis dan memberikan informasi ketinggian air kedalam LCD secara realtime dan selain memberikan informasi yang ditampilkan di LCD juga bisa memberikan informasi secara realtime melalui sistem perangkat lunak (software) web Service.

\section{Membuat Prototype}

Pada mekanisme ini menggunakan mikrokontroler dengan jenis Arduino UNO R3 dengan menambahkan sensor warna TCP 3200, sensor gerak, servo, LED, LCD (Liquid Crystal Display) sebagai interface sistem. Proses pembuatan prototype akan dibahas pada bab IV (empat) dipecah menjadi beberapa bagian yaitu:

1. Perancangan Sistem

2. Perancangan perangkat keras (Hardware) tentang rangkain hardware.

3. Perancangan Perangkat Lunak (Software) terdiri dari perangkat lunak pada Arduino UNO R3 (program).

4. Pembuatan alat peringatan dini banjir menggunakan sensor ultrasonik dan alat maket , pembuatan perangkat lunak pada Arduino UNO R3 (Program Pengendali).

\section{Menguji Prototype}

Untuk Pengujian perangkat keras ini adalah untuk menemukan kesalahan atau kekurangan dalam prototype sistem monitoring ketinggian air untuk peringatan dini banjir menggunakan Arduino UNO R3 dan sensor HC-SR04 khusunya dalam perangkat keras dan perangkat lunak yang digunakan dalam membangun sistem tersebut.

Selain menguji sistem dengan keseluruhan pada mekanisme ini juga dilakukan pengujian komponenkomponen yang digunakan. Pengujian ini akan dibahas pada bab IV (Empat). Pengujian yang dilakukan adalah :

1. Pengujian Perangkat Keras (Hardware) terdiri dari :
a. Pengujian sensor ultrasonik
b. Pengujian LED
c. Pengujian LCD
d. Pengujian Buzzer

2. Pengujian Perangkat Lunak (Software) terdiri dari :
a. Pengujian program Arduino
b. Pengujian keseluruhan system

\section{Memperbaiki Prototype}

Setelah dalam pemakaian dengan jangka waktu tertentu, terjadi ketidak sesuaian dengan yang diminta oleh pengguna (User), baik itu dari segi cara kerja keseluruhan sistem, perangkat keras maupu perangkat lunak yang digunakan pada sistem, maka perlu perbaikan atau modifikasi pada prototype tersebut.

\section{Mengembangkan Versi Produk}

Tahap terakhir adalah finishing dari produk tersebut. Sesuai dengan permintaan atau masukan dari pengguna guna melakukan pengembangan kearah yang lebih baik.

\section{HASIL DAN PEMBAHASAN. \\ a. Perancangan Sistem}

Dalam perancangan prototype sistem monitoring ketinggian air untuk peringatan dini banjir dengan mikrokontroler Arduino Uno R3 dan sensor HCSR04 ini terdapat tiga bagian utama yaitu bagian masukan (input), proses (process), keluaran (output). Tiga bagian ini merupakan dasar dalam penentuan kinerja pada prototype sistem monitoring ketinggian air untuk peringatan dini banjir. Tiga bagian ini harus 
saling terhubung dan memiliki hubungan satu sama lain. Bisa dikatakan bahwa ketika ketiga bagian itu ada maka sudah dikatakan itu merupakan sebuah sistem.

Bagian input pada sistem monitoring ketinggian air ini yaitu diambil dari sensor HC-SR04 (ultrasonic). Sensor ini akan mendeteksi ketinggian air secara realtime yang nantinya ketinggian ini akan menjadi sebuah input bagi sistem.

Setelah sensor HC-SR04 mendeteksi ketinggian air, maka masukan input tersebut akan diproses pada mikrokontroler Arduino Uno R3. Ketinggian tersebut akan diproses dan dimasukan kedalam tiga kategori sebagai berikut :

1. Ketinggian lebih dari $0 \mathrm{~cm}$ dan kurang dari $5 \mathrm{~cm}$, maka kondisi aman dan output-nya LED aman menyala.

2. Ketinggian lebih dari $5 \mathrm{~cm}$ dan kurang dari 10 cm, maka kondisi waspada, output-nya LED waspada menyala dan mengirim DATA.

3. Ketinggian lebih dari $10 \mathrm{~cm}$ dan kurang dari 15 $\mathrm{cm}$, maka kondisi siaga output-nya LED siaga menyala dan mengirim DATA.

4. Ketinggian lebih dari $15-20 \mathrm{~cm}$, maka kondisi banjir, output-nya LED banjir menyala, buzzer berbunyi, dan mengirim DATA.

Sehingga output-nya yaitu sebagai berikut :

1. Alarm peringatan yaitu berupa speaker dan LED.

2. Menampilkan status sistem pada LCD.

3. Mengirimkan status data sistem ke web service dari mikrokontroler melalui Bluetooth.

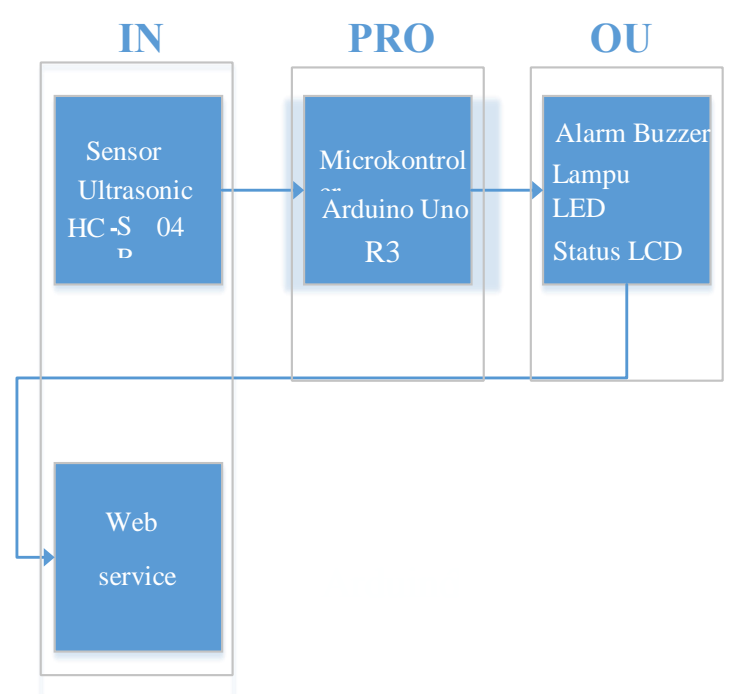

Gambar 5. Diagram Sistem

Gambar 5 diatas merupakan blok diagram keseluruhan sistem. Dimana blok diagram tersebut terdiri dari input yang diambil dari sensor ultrasonik yang membaca ketinggian air.

Berdasarkan dari gambar 4.2 mengenai blok diagram keseluruhan sistem maka penjelasannya yaitu sebagai berikut :

1. Pada saat pertama kali rangkaian sistem dinyalakan maka yang dilakukan oleh sistem yaitu menginisialisasikan pin-pin yang ada pada mikrokontroler Arduino Uno R3 baik itu pin input, output, maupun untuk power.

2. Pada saat sistem aktif, maka sistem sudah siap untuk menerima input yang berasal dari sensor ultrasonik (HC-SR04).

3. Ketika sensor ultrasonik mendeteksi ketinggian dan ketinggian air yang dibaca oleh sensor telah melebihi kapasistas ketinggian normal air, maka data tersebut akan diproses oleh mikrokontroler Arduino Uno R3. Dan akan ditampilkan kedalam LCD yang berukuran 20 (kolom) x 4 (baris).

4. Pada saat sistem mendeteksi banjir, maka akan ada output berupa suara sirine dari buzzer dan sistem juga akan mengirimkan data ke sebuah web service.

5. Setelah air mulai surut dan sudah tidak dalam keadaan banjir maka sistem akan berhenti.

\section{b. Pembuatan Perangkat Lunak}

Pada bagian ini menjelaskan tentang pembuatan sistem monitoring ketinggian air dalam segi perangkat keras yaitu pembuatan prototype simulasi banjir.

Penjelasan rangkaian skematik sistem monitoing ketinggian air adalah sebagai berikut :

1. Prototype sistem monitoring ketinggian air untuk peringatan dini banjir dengan menggunakan mikrokontroler Arduino Uno R3 dan sensor HCSR04 merupakan sistem yang memerlukan daya 5-12 Volt sesuai dengan spesifikasi dan kemampuan dari Arduino Uno R3. Sistem monitoring ketinggian air ini bisa menggunakan battery 9 Volt atau powerbank dengan output 512 Volt DC yang dihubungkan ke pin power (untuk battery) atau port USB (untuk powerbank) pada Arduino Uno R3.

2. Perangkat keras yang digunakan dalam membuat sistem keamanan ini dihubungkan sengan mikrokontroler Arduino Uno R3 sebagai pengontrolnya menggunakan kabel ke pin-pin I/O pada mikrokontroler tersebut. Penyambungan perangkat keras dengan pin I/O Arduino. 
3. Tiap perangkat keras yang digunakan minimal terdiri dari Ground/GND dan VCC. Untuk perangkat keras tertentu VCC dapat disambungkan dengan pin $\mathrm{I} / \mathrm{O}$ pada mikrokontroler sedangkan GND tetap dihubungkan ke GND yang ada di pin Arduino Uno R3. Pada sistem monitoring ketinggian air usulan ini perangkat keras yang digunakan yaitu LED dan buzzer memiliki 2 pin. Sedangkan perangkat keras lainnya memiliki lebih dari 2 pin.

4. Setiap LED menggunakan resistor dengan besar hambatan $220 \mathrm{ohm}$. Pin VCC pada LED dihubungkan ke pin D10, D11, D12, D13 pada Arduino karena terdapat 4 LED.

5. Pin VCC pada sensor ultrasonik (HC-SR04) dihubungkan ke pin 5 volt, GND dihubungkan ke GND, trig dihungkan ke A2 dan echo dihubungka ke A3.

6. Untuk Bluetooth HC-05, dan LCD 20x4 (termasuk modul I2C+SPI Backpack) memiliki 2 pin tambahan selain GND dan VCC. LCD 1 pin tambahan tersebut adalah SCL dan SDA (pin A5 pada Arduino Uno R3) sebagai pin output dari LCD. Bluetooth HC-05 memiliki 2 tambahan pin yaitu RX (Receiver) dan TX (Transmitter) sebagai pengirim dan penerima data dari koneksi Bluetooth. Pin RX dan TX dihubungkan dengan pin D0 dan D1 (TX dan RX) pada Arduino Uno R3.

7. Karena VCC dan GND terbatas dalam pin Arduino Uno R3, dimana GND hanya terdapat 2 pin dan VCC hanya terdapat 2 pin (5 Volt dan 3,3 Volt), maka pin VCC dan GND di jumper ke media penghubung yang dinamakan breadboard.

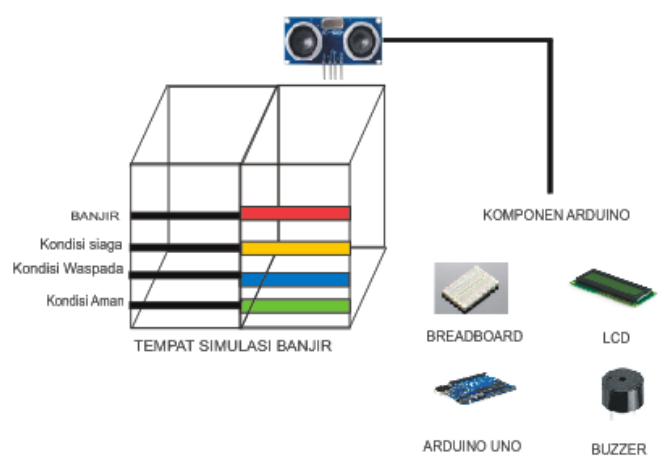

Gambar 6. Skema prototype Sistem Monitoring Ketinggian Air

Penjelasan tentang Skema prototype monitoring ketinnggian air yang di buat adalah sebagai berikut :
1. Skema prototype ini terdiri dari 2 tempat simulasi banjir dan box komponen Arduino Uno R3. Tempat simulasi banjir dibuat dari kaca dengan tebal kaca 5 inc dan berbentuk balok dengan ukuran luas alas $40 \mathrm{~cm} \times 20 \mathrm{~cm}$ dan tinggi $50 \mathrm{~cm}$. Tempat simulasi banjir ini dibagi menjadi 2 yaitu tempat untuk memonitoring ketinggian airnya, dan tempat untuk pembuangan air apabila terjadi banjir.

Sedangkan tempat simulasi yang kedua yaitu komponen perangkat Arduino Uno R3 dan komponen lainnya yang disimpan dalam sebuah box.

2. Setelah sistem aktif maka air akan masuk pada tempat simulasi banjir dan ketinggian air akan dideteksi oleh sensor ultrasonik (HC-SR04) yang akan diproses oleh Arduino Uno R3 yang berada dalam sebuah box.

3. Ketinggian air bersifat kondisi aman apabila air masih dibawah garis warna hijau, apabila air berada diatas garis warna hijau maka kondisi Waspada, apabila ketinggian air melebihi garis warna biru maka kondisi Siaga, dan apbila ketinggian air melebihi garis warna merah maka kondisi banjir.

4. Informasi mengenai ketingggian air, volume air dan keterangan status ditampilkan di LCD 20x4 yang berada pada box komponen.

\section{c. Pembuatan Perangkat Keras}

Pada bagian ini berisi tentang pembuatan perangkat lunak untuk membangun prototype sistem monitoring ketinggian air untuk peringatan dini banjir menggunakan mikrokontroler Arduino Uno R3 dan sensor HC-SR04. Perangkat lunak yang akan dibuat yaitu program pada Arduino Uno R3 :

1. Program pada Arduino Uno R3

Pembuatan program pengendali pada Arduino Uno R3 menggunakan tools Arduino IDE 1.6.5. cara kerja dari program untuk mengendalikan prototype sistem monitoring ketinggian air ini dapat dilihat pada gambar 4.9 dibagian perancangan perangkat lunak. Pembuatan program ini disajikan berupa screenshoot yang ada di lampiran. Program ini terdiri dari :

A. Inisialisasi pin

Inisialisasi pin pada program Arduino ini merupakan bagian keseluruhan program flood monitoring yang berfungsi sebagai inisialisasi perangkat keras yang terhubung dengan pin Arduino Uno R3. Inisialisasi pin ini terdiri dari input dan output.

Input ini terdiri dari Sensor HC-SR04 yang disimpan dalam variable dengan tipe integer yaitu

Computer Science | Industrial Engineering | Mechanic Engineering | Civil Engineering 248 
trigPin yang dihubungkan pada pin A2 (Analog 2) dan echoPin yang dihubungkan pada pin A3 (Analog 3) serta pin VCC yang dihungkan ke pin 5 Volt dan GND yang dihubungkan pada GND, namun 2 pin ini yaitu VCC dan GND tidak dideklarasikan dalam program.

Input yang satu lagi yaitu keypad yang memiliki 8 pin. Keypad ini dihubungkan ke pin D2,D3,D4,D5,D6,D7,D8, dan D9 di Arduino.

Output terdiri dari LED indikator pada sistem monitoring ketinggian air ini berjumlah 4 buah yaitu LED "Kondisi Aman" dihubungkan ke pin D10 (Digital 10), LED "Kondisi Waspada" dihubungkan ke pin D11 (Digital 11), LED "Kondisi Siaga" dihubungkan ke pin D12 (Digital 12), dan LED "Kondisi Banjir" dihubungkan ke pin D13 (Digital 13).

Buzzer / speaker disimpan dalam variable pinSpeaker dengan tipe data integer dihubungkan ke pin A0 (Analog 0). Selain LED dan buzzer yang termasuk perangkat keras output adalah servo dan LCD.

\section{B. Melihat data pada koneksi Bluetooth}

Bagian ini menjelaskan tentang koneksi Bluetooth yang terjadi dalam sistem monitoring ketinggian air. Koneksi ini menghubungkan antara prototype sistem monitoring air Pertama yang dilakukan adalah menambahkan Code "Serial.begin(9600);" ini murupakan kode untuk menampilkan data yang diterima oleh inputan sensor ultrasonik berupa ketinggian air. Selain itu mendeklarasikan RX dan TX pada pin D0 dan D1 di Arduino untuk transferring data. Setiap data yang ditampilkan di serial BAUD 9600 akan dikirimkan ke web service dengan media transmisi Bluetooth.

\section{Mendeteksi ketinggian air}

Bagian ini menjelaskan mengenai sensor ultrasonik yang bisa mendeteksi ketinggian air. Untuk sensor ultrasonic terdapat 4 pin yaitu VCC, GND, trig dan echo. VCC dan GND tidak dideklarasikan dalam program, yang dideklarasikan hanya pin trig ke pin A2 (Analog 2) dan pin echo ke A3 (Analog 3).

Fungsi yang dipanggil atau digunakan untuk menjalankan sensor ultrasonik yaitu "void ultrasonic()". Dalam void tersebut terdapat perhitungan untuk mendapatkan ketinggian air dan volume air. Fungsi ini dipanggil di "void $\operatorname{loop}() ; "$ sehinggal fungsi ini akan terus berulang selama user belum menonaktifkan sistem tersebut.

\section{Pengujian Perangkat Keras}

Pengujian perangkat keras ini adalah untuk menemukan kesalahan atau kekurangan dalam prototype sistem monitoring ketinggian air untuk peringatan dini banjir menggunakan Arduino UNO R3 dan sensor HC-SR04 khusunya dalam perangkat keras yang digunakan dalam membangun sistem tersebut.

\section{Pengujian sensor ultrasonic HC-SR04}

Tujuan pengujian dan analisis atau pembahasan yang dilakukan pada sensor ultrasonic HCSR04 adalah untuk mendapatkan parameter tentang keakuratan jarak yang dideteksi oleh sensor. Hal ini dilakukan untuk mendapatkan hasil yang maksimal terhadap ketinggian air yang dideteksi.

\begin{tabular}{ccc}
\hline No & Level Terukur $(\mathbf{c m})$ & $\begin{array}{l}\text { Level Terdeteksi } \\
\text { sensor Ping }(\mathbf{c m})\end{array}$ \\
\hline $\mathbf{7}$ & 7 & 7 \\
\hline $\mathbf{8}$ & 8 & 8 \\
\hline $\mathbf{9}$ & 9 & 9 \\
\hline $\mathbf{1 0}$ & 10 & \\
\hline
\end{tabular}

\section{Pegujian Alarm (Buzzer dan LED)}

Pengujian alarm ini bertujuan untuk mengetahui indikator ketika ketinggian air melebihi batas normal sehingga status keamanan menjadi "Banjir". Pengujian alarm ini dikhususkan untuk mengetahui fungsi dari LED dan buzzer sebagai indikator. Pengujian ini bisa dilihat pada tabel sebagai berikut :

\section{Pengujian LED Aman}

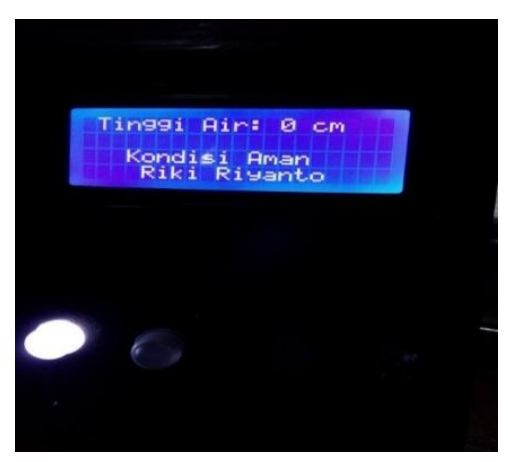

2. Pengujian LED waspada 


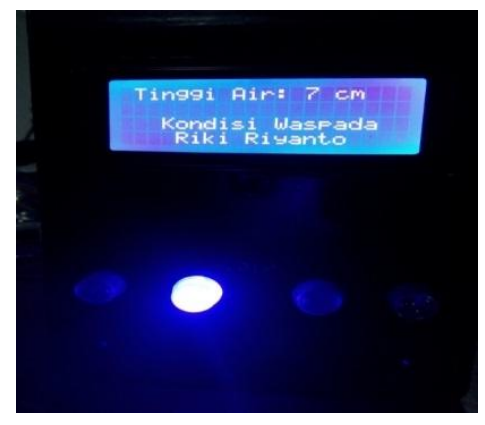

3. Pengujian LED siaga

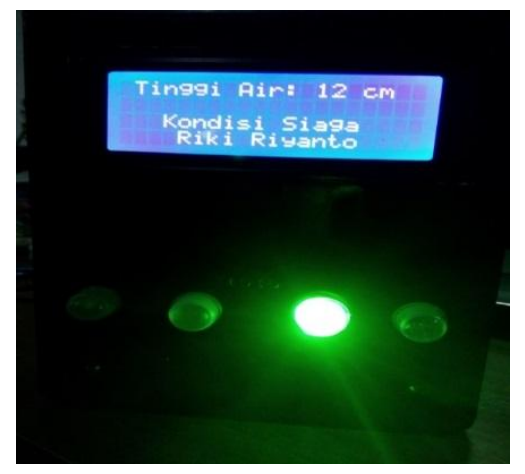

4. Pengujian LED banjir

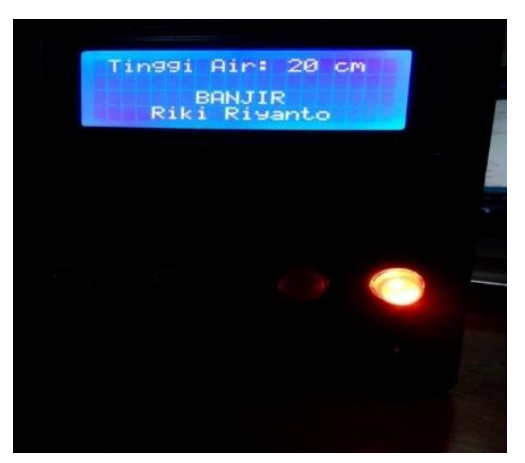

\begin{tabular}{|c|c|c|c|}
\hline No & $\begin{array}{c}\text { Sensor } \\
\text { Ultrasonic } \\
(\mathrm{cm})\end{array}$ & LED & Buzzer \\
\hline 1 & $\begin{array}{l}\text { Ketinggian } 0 \\
\mathrm{~cm}\end{array}$ & Menyala & Mati \\
\hline 2 & $\begin{array}{l}0<\text { Ketinggian } \\
<5\end{array}$ & Menyala & Mati \\
\hline 3 & $\begin{array}{l}6 \text { Ketinggian < } \\
10\end{array}$ & Menyala & Mati \\
\hline 4 & $\begin{array}{l}11< \\
\text { Ketinggian< } \\
15\end{array}$ & Menyala & Mati \\
\hline 5 & $\begin{array}{l}\text { Ketinggian > } \\
16\end{array}$ & Menyala & Berbunyi \\
\hline
\end{tabular}

Berdasarkan dari hasil penelitian alarm pada tabel di atas maka LED dan buzzer akan menyala berdasarkan dari ketinggian air yang dideteksi oleh sensor ultrasonic dan sesuai dengan program yang telah dirancang dan dibuat pada sketch Arduino Uno R3.

\section{KESIMPULAN}

Adapun kesimpulan yang dapat diambil dalam penelitian adalah sebagai berikut:

1. Alat yang dirancang mampu memonitoring ketinggian aktifitas air pada waduk serta mengontrol secara otomatis sesuai ketinggian aktifitas air, dan juga mempunya LED sebagai penanda level ketinggian air, LCD grafik yang mampu memvisualisasikan aktifitas air dalam bentuk grafik bar dan buzzer sebagai penanda bunyi pada ketinggian maksimal aktifitas air dan bluetooth sebagai pengirim data kesebuah web service.

2. Pemanfaatan sensor ping ultrasonic sebagai input dan mikrokontroler Arduino Uno R3 sebagai pusat pengolahan dari input sehingga menghasilkan output dari LCD grafik, LED, Buzzer dan web service.

3. Prototype sistem monitoring ketinggian air untuk peringatan dini banjir menggunakan mikrokontroler Arduino Uno R3 dan sensor HCSR04 ini dirancang dan dibuat menggunakan metode Prototype. Sensor HC-SR04 mendeteksi ketinggian air dengan memanfaatkan pemantulan gelombang elektromagnetik yang dihitung menggunakan rumus $\mathrm{T}=\mathrm{V}_{1}-\mathrm{V}_{2}, \quad$ yang diintegrasikan dengan mikrokontroler Arduino Uno R3 dengan menggunakan Bahasa pemrograman $\mathrm{C}$.

\section{REFERENSI}

Nugroho 2016,. “jumlah kejadian bencana di indonesia"

http://www.tribunnews.com/nasional/2016/12/2 9/bnpb-catat-sepanjang-2016-terjadi bencana-diindonesia. (juli 20 2017).

Purnomo dan pramana, arduino 2015 "mengenal arduino software (ide, Http://www.sinauarduino.com/artikel/mengenalarduino-software-ide/, ( juli 20 2017).

Sakti, e, mei 2014, http://elangsakti.com/2014/05/sensorultrasonik.html/...(diakses juli 20, 2017).

Kadir, a.2003. "pengenalan sistem informasi". Yogyakarta: andi, di akses ( juli 20 2017). 